$\begin{gathered}\text { Journal of Business Management and } \\ \text { Economic Research }\end{gathered}$
2019, 3 (2): 42-55 DOI: 10.29226/TR1001.2019.108
Journal Homepage: https://www.jobmer.org

\title{
Determinants of Career Choice Among Secondary Schools Students: Evidence From Selected Secondary Schools in Tanzania
}

\author{
Trishala Ravichandra Vaghela ${ }^{1}$ \\ Ruaha Catholic University, trishala.vaghela123@gmail.com \\ Hadija Matimbwa ${ }^{2}$ \\ Department of management science and procurement, Ruaha Catholic University \\ hadija.matimbwa@gmail.com
}

\begin{abstract}
The purpose of the study was to investigate the psychosocial determinants of career choice among secondary school students in Iringa Municipality. The study identified the career services available at Secondary schools, also determined psychological and social factors determining career choices in the selected secondary schools in Iringa Municipality. The study employed mixed approach. This study adopted case study design and Questionnaires were used as the survey instrument. Then probability sampling was used to select a representative sample. A sample size of 100 students was taken and interview guide for 30 who were teachers and head of schools. The data were collected by using structured questionnaires and interview guide. Descriptive statistics used to analyze data collected from the respondents and SPSS version 20 and excel Microsoft application were used to process data. Findings of the study revealed that respondents denied that their schools to have career visits and career counselors. Also majority of respondents disagreed with the statement that "The school has career instructional materials". Furthermore the study found majority of respondents admitted to choose subjects of their interests and their personality were the reasons why they do belong to certain streams, lastly respondents $89 \%$ admitted they are so cautiously with the future life in terms of career, $84 \%$ agreed they are so confident on their potentials and talents they hold. Furthermore the study found there is positive strong relationship between psychological factors and career choice but social factors was found to weak relationship.
\end{abstract}

Keywords: Career choice, Psychosocial 
Journal of Business Management and Economic Research, vol.3, issue.2, pp.42-55

\section{Background of the Study}

Career refers to a variety of work and non-work situations which usually span through the entire life of an individual, it is generally related to a pattern of decision, transaction and adjustments which affects one's role in work, education, family, community development and leisure (Okobiah and Okorodudu, 2004).

Career selection is one of many important choices students will make in determining future plans, this decision will move them throughout their lives, the spirit of who the student is will revolve around what the student want to do with their life- long work, a lot of students in secondary schools believe that their future is a wonderful journey in which they are bound to succeed and many of them have the idea that they would be able to work in the public or private establishments as soon as they complete secondary school education. Some have planned to become lawyers, engineers, medical doctors, accountants and so on (Olamide and Olawaiye, 2013).

Career choice has been a difficult decision for secondary students since it determines the kind of profession that a student intends to pursue in their life, Students face problems when trying to make choice on which career to major by matching their preferences with their abilities in academic performance and in most cases the choice of career subjects, courses of study and the subsequent career path to follow are nightmare for future, students more often choosing the right subjects combination leading to the right professional can make a difference between enjoying and hating the career in future (Koech et al, 2016).

Ndalichako and Komba (2014), argued that, in Tanzania context students join secondary schools are supposed to take nine subjects, namely mathematics, English, Kiswahili, Biology, Physics, Chemistry, Geography, and History. In the third year students are allowed to choose one for the following options; science, business, agriculture science, technical and home economics, they also added that, students are expected to select subject that suit their interest and abilities. The increasing in experiences gained in form I and II serve as a basis for students in deciding which subjects to take in form III. It is worth mentioned that secondary school education in Tanzania is the gateway to future career opportunities, the subjects selected by students automatically dictate the kind of career path they will enter.

Students in secondary schools like many other young adults are always worried about what they will do with their lives, the kind of adult they will become, to them career choice has become a delicate issue that requires caution and serious considerations, planning for tomorrow itself is primarily the responsibilities of the parents, teachers and school counselors since students need general orientation (Wattles, 2009). An individual should have a true reasoning on the relations of her/himself and the requirements of success, occupations are chosen to meet needs but the decision making to this selection is guided by information and awareness about students themselves, career and occupation (Mabula, 2012).

It has been recognized recently that for a person to make realistic decision on career choice, many factors can be influential, it is one thing to demonstrate interest in a particular occupational field and it is another thing to have confidence and ability to successfully undertake the task involved and be able to belong in a certain career (Olamide and Olawaiye, 2013).

According to Brown (2002) the process of choosing a career is described as one of estimating one's ability and skills required for success in a given occupation, and estimating the work values that 
will be satisfied by the various occupational alternatives available. Brown added that, the essence of who the student is willing to be in future, revolve around what the student wants to do with their life-long work. Parents, teachers, the society, and the government as the whole recognize the needs for the proper career guidance and development. Students are concerned about future work and occupations but are not sure which factors like money or prestige should influence one's choice for job; in fact, career information which is obtained at school through career programs can help many students to make right career decisions and pursue subject combinations which can lead them to their dreams (Kariuki, 2008).

Bandura et al(2001) state that; each individual undertaking the process is influenced by several factors including the context in which they live in their personal aptitudes, social contacts and educational attachments, factors that influence career choice can either be intrinsic or extrinsic or both, most of people are influenced by career that their parents favor while others follow career that their educational choices have opened for them and some choose their passion regardless of how much or little it will make them while others choose the careers that gives high income. Student perception of being suitable for particular job also has been found to be influenced by a number of factors including ethnic background, year in school, level of achievements, choice of science subjects, attitudes and differences in job characteristics (Mac Quaid and Bond, 2003).

A study on career choice in Ethiopia by Stebleton (2007) indicated that the students had an external locus of control and believes that there are numerous factors which influence their career choices; these factors include political and economic considerations, previous work experience and the influence of key individuals in person's life. Onyamo and Amoth (2008) said studies in Kenya show that rural students tend to seek help from parents more than urban students and that parents play a major role in the career choice of students more than teachers. In Tanzania different factors were found as determinants of career choice among high school students in Dar es Salaam, these includes good experience from the work of professionals, professionals who are attractive to respondents and professionals who command high respect in the community were perceived as important factors, also knowledge about work to be done and advice from important persons was perceived important (Mugonzibwa, et al., 2000).

However, these findings have not given us a clear picture of the Iringa context. Despite the available literature to the researchers' knowledge, none has been able to give a comprehensive picture of psychosocial determinants of career choice among secondary school students in Iringa municipality. Also many of the reviewed studies focused on the factors affecting career choice on universities and higher learning institutions and emphasize little about secondary schools while the foundation of future careers of individuals starts from there. Hence it is crucial to conduct the study on Psychosocial Determinants of Career choice among secondary school students in Iringa Municipality.

\section{Literature Review}

\subsection{Career services available at secondary schools.}

Mabula (2012) in his study on "Career Services Provision to Secondary School Students in Tanzania: Is it a dream or Reality?" examined the status of career services provision and its role on career decision making among high school students in Dar es Salaam, Tanzania by comparing career services provision in government and international schools with the intention of identifying the career programs available to students in schools, students' career knowledge and the contribution 
of career programs and career knowledge to students' career decision making. The study was conducted in six secondary schools using a sample of 322 students. The data from students were collected through a structured questionnaire and focus group discussions. The results revealed that students in international schools had access to many career programs and they have better knowledge on careers as compared to students in government schools. The study concluded that, career services provision in international schools is to some degrees a reality as opposed to government schools where career services provision is still a dream. It is suggested that, future research can observe the role of career services provision in secondary schools to students' ability to make relevant course choices in higher learning institutions. Critically, this study only focused on Career Services Provision to Secondary School Students in Tanzania contrary to the intended study which will focus on determinants of career choice among students in secondary schools in Tanzania specifically in Iringa municipality and career service provision will be a part of it. Biswalo (1996) explains that, the career services provision in many secondary schools in Tanzania is still less effective due to lack of trained career counselors, career instructional materials and related career facilities a factor which limits the knowledge of students on careers.

\subsection{Psychological determinants of career choice among secondary school students}

Hellman (2014) in his study titled "Social and Psychological Factors Related to Career Exploration Process of Young adults" examined social and psychological factors influencing the career exploration process of young adults in USA, the predictor variables of the study were parental attachment, peer attachment and self-efficacy, the outcome variables were environmental/ occupational exploration, self-exploration and career indecision. Data collection was through a survey presented on qualtrics. The results indicated that secure maternal attachment predicted secure peer attachment and high self-efficacy in young adults. Higher level of self-efficacy was positively correlated with environmental exploration and negatively correlated with career indecision. This imply that maternal attachment have an indirect influence on young adults career exploration and decision making.

Olamide and Olawaiye (2013) in their study titled "The Factors Determining the Choice of Career among Secondary School Students in Nigeria." Used a sample of 100 students who were randomly selected from five secondary schools in Ogun state. The sample consists of 37 males and 63 females. A questionnaire designed on the basis of Likert scale on the factors determining the choice of career based on environment, influence and opportunity of the students was administered. The analysis was through percentages, mean, standard deviation and T-test. Significant differences were found on personality factors, opportunity factors and environmental factors. The results also show that both factors affect student's career choice in different ways.

Obiunu and Ebunu(2011), Investigated on "Factors Affecting Career Development of Senior Secondary School Students in Ethiope East Local Government Area, Delta State, Nigeria" using the population of senior secondary school students. Simple percentage was used to analyze the data collected from the respondents. Some of the factors revealed to affect career development psychological factors such as interests, self-esteem, personality, values, norms and prestige, social factors such as peer groups, role models, mentors, social networks, social economic status of parents and family influences, educational factors such as skills, experiences, knowledge, information and other factors that could be product of teaching and learning. Heredity factors were also revealed. All of these were evidenced to play significant role in career decision making process 
of secondary school students. The findings also indicated that career counseling is required for appropriate career development.

\subsection{Social factors determining career choice among secondary school students}

Shumbal and Naong (2012), conducted a study titled "Factors Influencing Students Career Choice and Aspiration in South Africa" aimed to determine factors which influence career choice and aspiration in South African students; by using a quantitative methodology where by a survey in the form of structured questionnaire was used in a study. A purposive sample of 133 students participated, the career aspiration questionnaire was also used, and the data obtained were analyzed by using percentages and tables. The study found that the family influences, peers, the ability of the learner self to identify his/her preferred career choice and teachers were significant factors that influence the career choice and aspiration of students.

Mugonzibwa et al, (2000), identified the "Factors Influencing Career Choice among High School Students in Tanzania". A sample of 352 high school students from randomly selected high school were selected to complete a pre-tested questionnaire containing twenty four items addressing five factors. Image of a professional such as good experiences from the work of professionals, professionals who are attractive to respondents and professionals who command high respect in the community was perceived as important factor in career choice by majority of respondents (over 88 percent). Work/professional characteristics was ranked as the second most important factor in career choice and course characteristics were the third while direct gains and advice prom important persons were perceived as least important factors in career choice.

Naz, et al., (2014) in their empirical study on "Peer and Friends and Career Decision Making: A Critical Analysis" basing on content analysis as well as field information which explores the nature, level and extent of peer and friends influence in career decision making process of an individual. The data has been collected through library method i.e. searching relevant books, journals, articles, newspapers and even internet sources while field information has been obtained through questionnaires from 100 students using random sampling method. All the collected information have critically analyzed, debated and explained to produce theory for generalization and analysis of data was in the form of frequencies and percentages through chisquare test. The analysis and discussion thus give rise to an argument that although family i.e. Parents and other family members primarily geared and transformed the behavior of the children in multiple ways, however; peer influence is an asset for developing career opportunities and decision making among youth since peer and friends are important aspect of socialization process and their influence and pressure has also received wide acknowledgement in shaping and molding the course of an individual life.

Kala, (2015) in her study on "Parental and peer influence on career choice among secondary school students in Mombasa Sub-County" investigated parental and peer influence on career choice among secondary school students in Mombasa sub-county by using Self Determination Theory. Descriptive survey design was employed. The target population included form II students and parents who had schooled or were schooling children in secondary schools in Mombasa subCounty. Total respondents of 210 were used in the study. The study used the questionnaire and the interview guide as the major instruments for data collection. Data was analyzed descriptively with the use of Statistical package for Social Sciences (SPSS) version 18.0. The study found that parents 
who encouraged their children to follow their career path were major players in career selection of the student and the least influence of parental support was joining higher learning institutions.

Koech, et al. (2016), on his study on '"Factors Influencing Career Choices among Undergraduate Students in Public Universities in Kenya," examined the factors that influence career choices among students which attempt to unravel the secret surrounding career choices amongst students, the targeted population was undergraduate students at the University of Eldoret. A study sample of 210 was obtained by using a convenience sampling technique. The study used a descriptive research design where by data collection instrument used was a self-administered questionnaire which contained both open and closed ended questions factors of interest included were peer influence, gender, parental influence, job opportunities and personal interest. Results indicated that multiple factors such as parental influence determine career choices of undergraduate students.

\subsection{Conceptual Framework}

Figure2.1. Conceptual framework

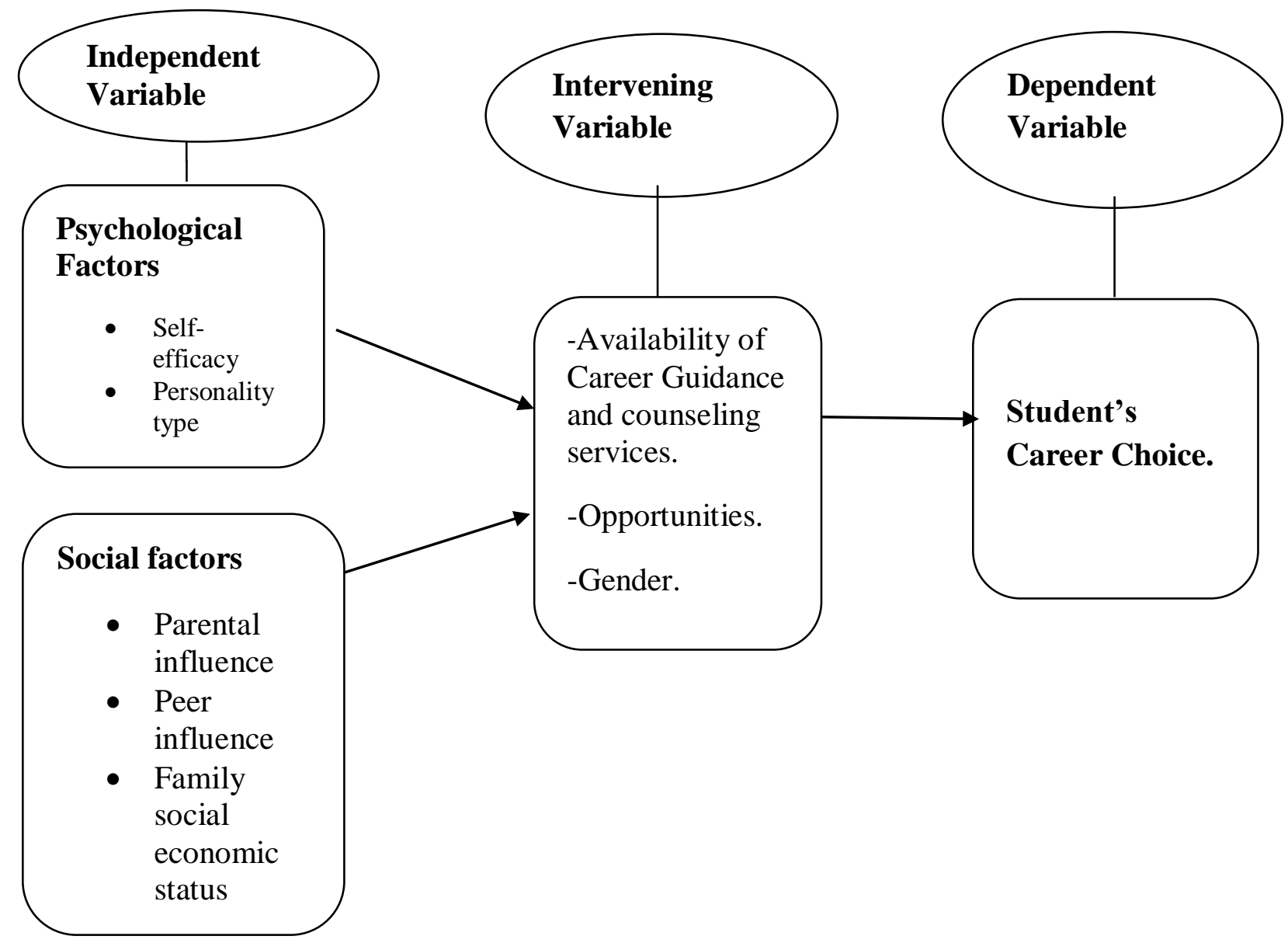

Source: Synthesized from literature reviewed (2018). 


\section{Research Methodology}

The study employed mixed approach i.e. quantitative and qualitative approaches. This study adopted case study design to assess the psychosocial determinants of career choice among secondary schools. Questionnaires were used as the survey instrument. Then probability sampling was used to select a representative sample. A sample size of 100 students was taken and interview guide for 30 who were teachers and head of schools. The data were collected by using structured questionnaires and interview guide. Descriptive statistics and were used to analyze data collected from the respondents and SPSS version 20 and excel Microsoft application were used to process data.

\section{Results}

\subsection{Demographic characteristics}

In this study, in order to have a better understanding on the demographic characteristics and specifications of the respondents, frequency analysis has been used. The samples of the questionnaires were taken from selected secondary schools in Iringa Municipality which consisted of 100 sample size. Totally, there were five questions that give a brief overview of demographic attributes of respondents. As presented in Table 1

Table 1: Sample characteristics

\begin{tabular}{|c|c|c|c|}
\hline Variable & Categories & Frequency & Percentage $(\%)$ \\
\hline \multirow[t]{2}{*}{ Sex } & Male & 45 & 45.0 \\
\hline & Female & 55 & 55.0 \\
\hline \multirow[t]{3}{*}{ Age } & $12-14$ & 31 & 31.0 \\
\hline & $15-17$ & 67 & 67.0 \\
\hline & $18-20$ & 2 & 2.00 \\
\hline \multirow[t]{2}{*}{ Class representation } & Form III & 61 & 61.0 \\
\hline & Form IV & 39 & 39.0 \\
\hline \multirow[t]{5}{*}{ Stream representation } & Science & 55 & 55.0 \\
\hline & Arts & 24 & 24.0 \\
\hline & Agriculture & 2 & 2.0 \\
\hline & Business & 17 & 17.0 \\
\hline & Domestic Science & 2 & 2.0 \\
\hline \multirow[t]{6}{*}{ School representation } & Lugalo & 25 & 25.0 \\
\hline & Klerruu & 18 & 18.0 \\
\hline & Mlamke & 14 & 14.0 \\
\hline & Iringa Girls & 21 & 21.0 \\
\hline & Ipogolo & 7 & 7.0 \\
\hline & Miyomboni & 15 & 15.0 \\
\hline
\end{tabular}

Source: field data (2018) 
The study involved a sample of $100(100 \%)$ respondents who filled the questionnaires. $45(45 \%)$ of total respondents were male and $55(55.0 \%)$ were female. This implies that there was a slight difference between male and female respondents. Therefore, gender was seriously taken into consideration to collect data from the respondents. Also about $67 \%$ of respondents fall in the age category of $15-17$, followed by $31 \%$ who had age between $18-20$ years, and the remaining $2 \%$ range from 12-14years.

Findings also revealed majority of the respondents were in form three who was 61(61\%) followed by form four who were 39(39\%). The reason behind why form four students were few was because by the time data collected these group were doing Mock Examination. The study statistics indicate that $25(25.0 \%)$ were respondents from Lugalo Secondary School, 18(18\%) were students from Kleruu Secondary, 14(14\%) from Mlamke Secondary School, 21 (21\%) were respondents from Iringa Girls, 7(7\%) from Ipogolo Secondary and the remaining 15(15\%) were from Miyomboni Secondary School. Therefore, the statistics shows that most of the respondents were from Lugalo and Iringa Girls Secondary Schools.

Respondents were asked to state stream they have opted. The study statistics indicate that $55 \%$ of respondents studied science, followed by $24 \%$ arts, $17 \%$ were studied business, and $2 \%$ studied Agriculture and Domestic science respectively. Therefore, the statistics shows that most of the respondents were studied science and Arts. This is because most of these schools have science and arts streams.

\subsection{Career services available in Selected Secondary Schools in Iringa}

In identification of career choices available in the selected secondary schools in Iringa Municipality, the researcher formulated several statements whereby the respondents were asked to jot down for the purpose of showing their levels of agreement on availability of career choices in their schools. Findings as indicated below;

Table 2: Career services available in selected secondary schools

\begin{tabular}{|l|c|c|c|c|c|}
\hline & $\begin{array}{l}\text { Strongly } \\
\text { Disagree }\end{array}$ & Disagree & Neutral & Agree & $\begin{array}{c}\text { Strongly } \\
\text { Agree }\end{array}$ \\
\hline & Percentage (Frq) & Per (Frq) & Per (Frq) & Per (Frq) & Per (Frq) \\
\hline The school has career visit & $41(41.0)$ & $23(23.0)$ & $20(20.0)$ & $15(15.0)$ & $1(1.0)$ \\
\hline $\begin{array}{l}\text { The school has trained career } \\
\text { counselor }\end{array}$ & $31(31.0)$ & $24(24.0)$ & $8(8.0)$ & $23(23.0)$ & $14(14.0)$ \\
\hline $\begin{array}{l}\text { The school has career } \\
\text { instructional materials }\end{array}$ & $37(37.0)$ & $19(19.0)$ & $17(17.0)$ & $22(22.0)$ & $5(5.0)$ \\
\hline $\begin{array}{l}\text { I have enough knowledge on } \\
\text { how to choose career }\end{array}$ & $22(22.0)$ & $17(17.0)$ & $18(18.0)$ & $28(28.0)$ & $15(15.0)$ \\
\hline $\begin{array}{l}\text { The school conduct career } \\
\text { exhibition to students }\end{array}$ & $45(45.0)$ & $14(14.0)$ & $10(10.0)$ & $19(19.0)$ & $12(12.0)$ \\
\hline
\end{tabular}


Journal of Business Management and Economic Research, vol.3, issue.2, pp.42-55

\begin{tabular}{|l|c|c|c|c|c|}
$\begin{array}{l}\text { We have career clubs in our } \\
\text { schools }\end{array}$ & $27(27.0)$ & $10(10.0)$ & $6(6.0)$ & $38(38.0)$ & $19(19.0)$ \\
\hline $\begin{array}{l}\text { The school has many career } \\
\text { programs }\end{array}$ & $35(35.0)$ & $16(16.0)$ & $23(23.0)$ & $18(18.0)$ & $8(8.0)$ \\
\hline
\end{tabular}

Source: field data (2018)

The data in the table 2 indicates that, $64 \%$ of the respondents denied that their schools to have career visits, 55\% also disagreed that to have trained career counselors in their schools, 56\% disagreed with the statement that "The school has career instructional materials". Moreover on whether they have enough knowledge on how to choose career $43 \%$ disagreed only $42 \%$ agreed to have the knowledge. Furthermore, 59\% of the respondents denied having career exhibition in their schools, while $56 \%$ admitted to have career clubs in their schools, lastly $51 \%$ of all respondents denied to have many career programs in their schools. Based on these findings it imply that majority of the selected secondary schools in Iringa Municipality have no career services in their respective schools, only few schools have career clubs which are not enough for the students to get the required advices on how to choose the career.

\subsection{Psychological factors determining career choice among secondary school students in Iringa Municipality}

In determining psychological factors which determine career choices among secondary school students in Iringa several questions were posed, and respondents were supposed to show their level of agreement. Table 3 below illustrate

Table 3 Psychological factors influencing career choice

\begin{tabular}{|l|c|c|c|c|c|}
\hline & $\begin{array}{c}\text { Strongly } \\
\text { Disagree }\end{array}$ & Disagree & Neutral & Agree & $\begin{array}{c}\text { Strongly } \\
\text { Agree }\end{array}$ \\
\hline $\begin{array}{l}\text { Percentage } \\
\text { (Frq) }\end{array}$ & Per (Frq) & Per (Frq) & Per (Frq) & Per (Frq) \\
difficult problems in my studies & $11(11.0)$ & $4(4.0)$ & $10(10.0)$ & $53(53.0)$ & $22(22.0)$ \\
\hline $\begin{array}{l}\text { It is easy for me to stick to my } \\
\text { aims and accomplish my goals in } \\
\text { my studies }\end{array}$ & $4(4.0)$ & $6(6.0)$ & $11(11.0)$ & $46(46.0)$ & $33(33.0)$ \\
\hline $\begin{array}{l}\text { I can solve most problems facing } \\
\text { my studies if I invest the } \\
\text { necessary effort }\end{array}$ & $3(3.0)$ & $3(3.0)$ & $5(5.0)$ & $46(46.0)$ & $43(43.0)$ \\
\hline $\begin{array}{l}\text { I believe that am capable of } \\
\text { choosing any career I want } \\
\text { without being forced by any one } \\
\text { because I'm doing well in my } \\
\text { studies }\end{array}$ & $9(9.0)$ & $5(5.0)$ & $6(6.0)$ & $34(34.0)$ & $46(46.0)$ \\
\hline $\begin{array}{l}\text { I can remain calm when facing } \\
\text { difficulties because can rely on }\end{array}$ & $9(9.0)$ & $12(12.0)$ & $17(17.0)$ & $31(31.0)$ & $31(31.0)$ \\
\hline
\end{tabular}


Journal of Business Management and Economic Research, vol.3, issue.2, pp.42-55

\begin{tabular}{|l|c|c|c|c|c|} 
my coping abilities & & & & \\
\hline $\begin{array}{l}\text { I am capable of accomplishing } \\
\text { my study works at a time. When } \\
\text { I am confronted with a problem, I } \\
\text { can usually find several solutions }\end{array}$ & $3(3.0)$ & $5(5.0)$ & $17(17.0)$ & $38(38.0)$ & $37(37.0)$ \\
\hline $\begin{array}{l}\text { I am able to accomplish my } \\
\text { works without being helped by } \\
\text { others }\end{array}$ & $3(3.0)$ & $14(14.0)$ & $17(17.0)$ & $29(29.0)$ & $37(37.0)$ \\
\hline I choose subjects of my interests & $9(9.0)$ & $3(3.0)$ & $6(6.0)$ & $26(26.0)$ & $56(56.0)$ \\
\hline $\begin{array}{l}\text { My personality is the reason why } \\
\text { I belong to a certain stream }\end{array}$ & $6(6.0)$ & $9(9.0)$ & $7(7.0)$ & $32(32.0)$ & $46(46.0)$ \\
\hline $\begin{array}{l}\text { I am so cautiously with my } \\
\text { future life in terms of career }\end{array}$ & $2(2.0)$ & $4(4.0)$ & $5(5.0)$ & $30(30.0)$ & $59(59.0)$ \\
\hline $\begin{array}{l}\text { I am so confident on my } \\
\text { potentials and talents I hold }\end{array}$ & $4(4.0)$ & $6(6.0)$ & $6(6.0)$ & $38(38.0)$ & $46(46.0)$ \\
\hline
\end{tabular}

Source: field data (2018)

Findings in table 3 above found $75 \%$ of the respondents admitted that they are able to solve difficult problems in their studies, $79 \%$ agreed with the statement that "It is easy for me to stick to my aims and accomplish my goals in my studies" also 89\% agreed with the statement "I can solve most problems facing my studies if I invest the necessary effort".

Moreover $80 \%$ believed that they are capable of choosing any career without being forced by anyone, $62 \%$ also admitted to remain calm when facing difficulties because they can rely on coping abilities, $76 \%$ admitted to accomplish their work on time and without being forced by others. $80 \%$ they admitted to choose subjects of their interests, $78 \%$ admitted their personality were the reasons why they do belong to certain streams, and $89 \%$ admitted they are so cautiously with the future life in terms of career, $84 \%$ agreed they are so confident on their potentials and talents they hold.

\subsection{Social factors determining career choice among secondary school students in Iringa Municipality}

In examining social factors determining career choice several statements were posed and respondents were asked to show their levels of agreement or disagreement. Table 4 below illustrates

Table 4. Social factors determining career choice

\begin{tabular}{|l|c|c|c|c|c|}
\hline & $\begin{array}{c}\text { Strongly } \\
\text { Disagree }\end{array}$ & Disagree & Neutral & Agree & $\begin{array}{c}\text { Strongly } \\
\text { Agree }\end{array}$ \\
\hline & $\begin{array}{c}\text { Percentage } \\
(\text { Frq })\end{array}$ & Per (Frq) & Per (Frq) & Per (Frq) & Per (Frq) \\
\hline $\begin{array}{l}\text { My parents chose my secondary } \\
\text { school subject }\end{array}$ & $55(55.0)$ & $18(18.0)$ & $4(4.0)$ & $6(6.0)$ & $17(17.0)$ \\
\hline
\end{tabular}


Journal of Business Management and Economic Research, vol.3, issue.2, pp.42-55

\begin{tabular}{|l|c|c|c|c|c|}
$\begin{array}{l}\text { My career choice has been } \\
\text { influenced by the occupation of } \\
\text { my parents/close relatives }\end{array}$ & $30(30.0)$ & $15(15.0)$ & $11(11.0)$ & $19(19.0)$ & $25(25.0)$ \\
\hline $\begin{array}{l}\text { My parents always warned me } \\
\text { never to choose certain career } \\
\text { they won't like }\end{array}$ & $26(26.0)$ & $33(33.0)$ & $12(12.0)$ & $13(13.0)$ & $16(16.0)$ \\
\hline $\begin{array}{l}\text { My parents encourage me to } \\
\text { consider many different } \\
\text { educational and career options }\end{array}$ & $10(10.0)$ & $16(16.0)$ & $8(8.0)$ & $23(23.0)$ & $23(23.0)$ \\
\hline $\begin{array}{l}\text { My parents socio-economic status } \\
\text { determine my career }\end{array}$ & $35(35.0)$ & $18(18.0)$ & $8(8.0)$ & $11(11.0)$ & $28(28.0)$ \\
\hline $\begin{array}{l}\text { My parents tell me they have } \\
\text { high expectations for my career }\end{array}$ & $14(14.0)$ & $10(10.0)$ & $3(3.0)$ & $25(25.0)$ & $48(48.0)$ \\
\hline $\begin{array}{l}\text { My parents encouraged me to be } \\
\text { involved in extracurricular } \\
\text { activities }\end{array}$ & $16(16.0)$ & $16(16.0)$ & $14(14.0)$ & $27(27.0)$ & $27(27.0)$ \\
\hline $\begin{array}{l}\text { Opinions from my fellow } \\
\text { students affects my career choice }\end{array}$ & $25(25.0)$ & $21(21.0)$ & $18(18.0)$ & $16(16.0)$ & $20(20.0)$ \\
\hline $\begin{array}{l}\text { Peer advice plays crucial role in } \\
\text { my future career choices }\end{array}$ & $20(20.0)$ & $24(24.0)$ & $18(18.0)$ & $21(21.0)$ & $17(17.0)$ \\
\hline $\begin{array}{l}\text { Exchanging ideas with my peers } \\
\text { influences my career choices }\end{array}$ & $14(14.0)$ & $14(14.0)$ & $10(10.0)$ & $37(37.0)$ & $25(25.0)$ \\
\hline $\begin{array}{l}\text { I am afraid of making career } \\
\text { choice decisions due to peer } \\
\text { rejection }\end{array}$ & $47(47.0)$ & $20(20.0)$ & $5(5.0)$ & $11(11.0)$ & $17(17.0)$ \\
\hline
\end{tabular}

Source: field data (2018)

Results in 4 above found $73 \%$ denied that their parents to chose their secondary school subjects, $46 \%$ denied that their career choices has been influenced by the occupation of their parents/close relatives, $59 \%$ denied to be warned by their parents on how to choose a certain career, $46 \%$ admitted that their parents encourage them to consider many different educational and career options, 53\% denied their parents social status to determine their career, $73 \%$ admitted that their parents to tell them that they had high expectations for their career. Furthermore $54 \%$ admitted that their parents encouraged them to be involved in extracurricular activities, $46 \%$ denied that opinions from fellow students to affects their career choices. Moreover $44 \%$ also denied peer advices to play a crucial role in their future career choice, $62 \%$ admitted that exchanging of ideas with their peers influences their career choices, $67 \%$ denied to afraid of making career choice decisions due to peer rejections.

\subsection{Reliability of the Study}

The reliability of data instruments was evaluated through the Split-Half Reliability test that can be calculated through the reliability index by coefficient alpha, Kuder-Richardson formula 20 (KR-20) or the Spearman-Brown formula to determine how much error in a test score is due to poor test 
Journal of Business Management and Economic Research, vol.3, issue.2, pp.42-55

construction. However, the coefficient alpha or Cronbach's Alpha was used to evaluate the reliability of the study because "If you administer a Likert Scale or have another measure that does not have just one correct answer, the preferable statistic to calculate the split-half reliability is coefficient alpha or called Cronbach's alpha" (Korb, 2013).

Table 5 shows the value of the coefficient alpha or Cronbach's alpha as the research scale is 0.839 or $83.9 \%$. This gets over the percent of $80 \%$, which is an extra good value for the internal consequence of the conceptual construction of the investigated scale. Since the coefficient value of $\alpha=0.839$ was obtained, hence the reliability is excellent.

\begin{tabular}{|c|c|}
\hline \multicolumn{2}{|c|}{ Table 5 Reliability Statistics } \\
\hline Cronbach's Alpha & $\mathrm{N}$ of Items \\
\hline .839 & 38 \\
\hline
\end{tabular}

Source: Field data (2018)

\subsection{Validity of the Study}

The validity of the study was measured using the Kaiser-Meyer-Olkin (KMO) and Bartlett's Test of sphericity through the SPSS. Results extracted from SPSS are presented on the Table 6 below regarding the two hypotheses of factor analysis. From table 6, the researcher found a sample sufficiency index of KMO by Kaiser-Meyer-Olkin, which compares the sizes of the observed correlation coefficients to the sizes of the partial correlation coefficients for the sum of analysis variables, is 0.558 or $55.8 \%$, and it is reliable because it is above 0.5 or $50 \%$ which is the cut-off. In addition, supposition test of sphericity by the Bartlett test (Ho: All correlation coefficients are not quite far from zero) is rejected on a level of statistical significance $\mathrm{p}<0.0005$ for Approx, so that the second acceptance of factor analysis is satisfied.

Table 6 KMO and Bartlett's Test

\begin{tabular}{|c|c|c|}
\hline Kaiser-Meyer-Olkin Measu & g Adequacy. & .558 \\
\hline & Approx. Chi-Square & 30.113 \\
\hline Bartlett's Test of Sphericity & Df & 3 \\
\hline & Sig. & .000 \\
\hline
\end{tabular}

Source: Field data (2018)

\section{Conclusion}

The study conclude that most of the secondary schools in Iringa do not have career counsellors, career programs, career visits as well as career instructional materials which is a bad sign for the students because they will fail to choice their career correctly. Moreover the study concludes that most of the secondary schools in Iringa just have career clubs which are not enough for all students to get the required advices. Also study revealed majority of the respondents choose their career based on their personality and not influenced by their parents. 
Journal of Business Management and Economic Research, vol.3, issue.2, pp.42-55

\section{References}

Bandura A, et al.(2001). Self-efficacy beliefs as shapers of children's aspirations and career trajectories. Child Development, 72: 187-206.

Biswalo, M. P. (1996). An Introduction to Guidance and Counselling in Diverse African Contexts. Dar es Salaam: DUP

Brown, D. (2002). "The role of work and cultural values in occupational choice, satisfaction, and success: A theoretical statement." Journal of Counseling and Development, 80: 48-56.

Hellmann, J N., (2014). "Social and Psychological Factors Related to the Career Exploration Process of Young Adults" Theses and Dissertations--Family Sciences. Paper 19. http://uknowledge.uky.edu/hes etds/19

Kala, N. J. (2015). Parental and peer influence on career choice among secondary school students. a case study of Mombasa Sub-County. URI: http://ir-library.ku.ac.ke /handle/123456789/15115

Kariuki, K. (2008, April 6). An Easy to Read guide on Careers. Sunday Nation, p, 12.

Koech et al (2016). Factors Influencing Career Choices among Undergraduate Students in Public Universities in Kenya. Australian Journal of Commerce Study SCIE Journals. Evaluation and Policy Analysis, 4: 237-247.

Mabula, N. (2012). Career Services Provision to Secondary School Students in Tanzania: Is it a dream or Reality? International Journal of Learning \& Development ISSN 2164-4063 2012, Vol. 2, No. 2

Mugonzibwa, E. A., Kikwilu, E. N., Rugarabamu, P. N., \&Ntabaye, M. K. (2000). Factors Influencing Career Choice among High School Students in Tanzania (Abstract). American Journal of Dental Education, 64(6), 423-429.

McQuaid, R. and Bond, S. (2003). Gender stereotyping of career choice. Cited from http://www.careersscotland.org.uk.

Naz et al. (2014). Peer and Friends and Career Decision Making: A Critical Analysis. Middle-East Journal of Scientific Research 22 (8): 1193-1197, 2014 ISSN 1990-9233

Ndalichako, L .J. and Komba, A. A. (2014) Students' Subject Choice in Secondary Schools in Tanzania: A Matter of Students' Ability and Interests or Forced Circumstances? Open Journal of Social Sciences, 2, 49-56.http://dx.doi.org/10.4236/jss.2014.2800

Obiunu J and Ebunu O.R. (2011). Factors affecting career development of senior secondary school students in Ethiope east local government area, Delta state, Nigeria. Educational Research (ISSN: 2141-5161) Vol. 1(11) pp. 594-599.

Okobiah OC and Okorodudu R.I (2004). Issues, Concepts, Theories and Techniques of Guidance and Counselling, Benin City: Ethiope Publishing.

Olamide O.I and Olawaiye O.S (2013). The Factors Determining the Choice of Career among Secondary School Students. The International Journal of Engineering and Science (IJES) Volumel2 2319-1813ISSN (p):2319-1805www.theijes.com

Shumba1, A. and Naon, M. (2012). Factors Influencing Students' Career Choice and Aspirations in South Africa.Journal of Social Sciences, 33(2):169-178.

Stebleton, M. J. (2007) Career counseling with African immigrant colleges: theoretical approaches and implications for practice. Career Development Quartely, 55(4), 290-312

Oyamo, O. R. and Amoth D. (2008). "Choice of final year options by undergraduate students at the Moi School of Information Sciences." East African Journal of Information Science. 
Journal of Business Management and Economic Research, vol.3, issue.2, pp.42-55

Wattles, D.W. (2009). "The science of getting rich." Journal of developmental psychology.www.thescienceofgettingrich.net. 